\title{
Composition and Functional Properties of Yam Bean (Pachyrhizus spp.) Seed Flour
}

\author{
Abbas Kisambira ${ }^{1}$, John H. Muyonga ${ }^{1}$, Yusuf B. Byaruhanga ${ }^{*}$, Phinehas Tukamuhabwa ${ }^{2}$, \\ Silver Tumwegamire ${ }^{3}$, Wolfgang J. Grüneberg ${ }^{4}$ \\ ${ }^{1}$ School of Food Technology, Nutrition and Bio-Engineering, Makerere University, Kampala, Uganda \\ ${ }^{2}$ School of Agricultural Sciences, Makerere University, Kampala, Uganda \\ ${ }^{3}$ International Institute of Tropical Agriculture, Dar es Salaam, Tanzania \\ ${ }^{4}$ International Potato Centre, Lima, Peru \\ Email: ${ }^{*}$ ybbyaru@gmail.com, ${ }^{*}$ ybbyaruhanga@caes.mak.ac.ug
}

Received 1 April 2015; accepted 20 May 2015; published 26 May 2015

Copyright (C) 2015 by authors and Scientific Research Publishing Inc.

This work is licensed under the Creative Commons Attribution International License (CC BY).

http://creativecommons.org/licenses/by/4.0/

(c) (i) Open Access

\section{Abstract}

Yam bean (Pachyrhizus spp.) is legume crop that not only produces edible roots but also has a high yield of unutilized seeds. Although the yam bean seeds are rich in protein, they are not used due to a high content of toxic rotenone. In this study, yam bean seeds were detoxified and the nutritional and functional properties of their protein determined to assess the proteins' potential for applications. Seeds of 10 accessions ( 2 accessions of $P$. erosus, 4 accessions of $P$. ahipa and 4 accessions of $P$. tuberosus) were analyzed for proximate composition, pasting and functional properties (bulk density, least gelation concentration, water absorption capacity, oil absorption capacity, emulsifying capacity, emulsion stability, foaming capacity, foam stability and protein solubility). The results showed that yam bean seeds contained: $29.2-32.1 \mathrm{~g} / 100 \mathrm{~g}$ proteins, 31.3 - $33.0 \mathrm{~g} / 100 \mathrm{~g}$ carbohydrates, $24.1-25.6 \mathrm{~g} / 100 \mathrm{~g}$ total fat, $7.5-8.1 \mathrm{~g} / 100 \mathrm{~g}$ crude fiber and $3.4-4.1 \mathrm{~g} / 100 \mathrm{~g}$ ash. The defatted $P$. erosus seed flour contained $45.6-48.8 \mathrm{~g} / 100 \mathrm{~g}$ protein, 32.6 - $36.5 \mathrm{~g} / 100 \mathrm{~g}$ total carbohydrate, $6.7-7.1 \mathrm{~g} / 100 \mathrm{~g}$ crude fiber, $6.0-6.4 \mathrm{~g} / 100 \mathrm{~g}$ ash and $5.2 / 100 \mathrm{~g}$ crude fat. The defatted yam bean seed flour exhibited relatively high protein solubility $(68.0 \%-70.4 \%)$, least gelation concentration $(14 \%)$, water absorption capacity $(2.8 \%-2.9 \%)$ and oil absorption capacity (1.5\%). The defatted flour exhibited emulsifying capacity of $35.7 \%$ $36.0 \%$, emulsion stability of $33.2 \%-33.5 \%$, foaming capacities of $42 \%$ and foam stability of $25.1 \%$ $\mathbf{2 5 . 8 \%}$. With respect to pasting properties, the defatted yam bean seed flours exhibited pasting temperature of $80.0^{\circ} \mathrm{C}-81.3^{\circ} \mathrm{C}$, peak viscosity of $145.5-146.7 \mathrm{RVU}$, trough viscosity of 95.1 102.0 RVU, break down of 43.5 - $51.6 \mathrm{RVU}$, set back of 252.9 - 258.1 RVU and final viscosity of 348 - 360 RVU. The results show that yam bean seed has potential for use in both food and nonfood applications.

${ }^{*}$ Corresponding author.

How to cite this paper: Kisambira, A., Muyonga, J.H., Byaruhanga, Y.B., Tukamuhabwa, P., Tumwegamire, S. and Grüneberg, W.J. (2015) Composition and Functional Properties of Yam Bean (Pachyrhizus spp.) Seed Flour. Food and Nutrition Sciences, 6, 736-746. http://dx.doi.org/10.4236/fns.2015.68076 


\section{Keywords}

\section{Yam Bean Seed Flour, Proximate Composition, Functional Properties}

\section{Introduction}

The yam bean crop belongs to the genus Pachyrhizus and is a close relative of soybeans and phaseolus bean [1]. The genus has three cultivated species (P. erosus, $P$. ahipa and P. tuberosus) and two wild species ( $P$. panamensis and $P$. ferrugineus). It is adapted to a wide range of environmental conditions especially in the tropics and has high yields. The crop is mainly used for its tuberous storage roots as a food though it has a seed yield of up to $5.2 \mathrm{MT} / \mathrm{ha}$ and high 1000 seed weight (180 - $230 \mathrm{~g}$ ) [2]. Yam bean seeds are rich in protein (25.7 - 32.2 $\mathrm{g} / 100 \mathrm{~g})$ and lipids (21.8 - 25.8) [3] as well as carbohydrate (26.85 g/100g) [4]. However, the use of yam bean seeds is limited mainly because of the presence of the toxin-rotenone [3] [4].

There is a need to exploit the food (nutritional) and industrial potentials of yam bean seeds. However, this requires prior information and understanding of desirable functional properties and the behavior of the material in systems during processing, manufacturing, storage, preparation as well as consumption [5]. Over the past 30 years, the use of flour and protein concentrate from legume seeds have been on the increase because of greater knowledge of their functional properties, processing and nutritive value. While historically, soy bean has had a competitive advantage over other legume seeds, there is a need to identify, develop and explore other legume sources. The yam bean seeds (Pachyrhizus spp.) offer such an unexploited opportunity.

Yam bean is an underutilized crop and was only recently introduced in farming systems outside South America. There is relatively limited information on properties of yam bean seeds and their derivatives. The lack of information on many basic aspects of underutilized crops such as the yam bean hinders their development and sustainable utilization. There is a need to get more information and understand the characteristics of this crop for its optimal use and application in areas where it is newly introduced. Therefore, the objective of this study was to determine the nutrient composition of seeds of Pachyrhizus spp. as well as functional properties of its defatted seed flour as the first step in identifying potential food and technological applications.

\section{Materials and Methods}

\subsection{Sample Collection and Preparation}

Yam bean seed samples of P. ahipa, P. tuberosus and P. erosus were obtained from International Potato Center (CIP)-Uganda office. The seeds were planted and grown in Uganda at National Crops Resources Research Institute (NaCRRI)-Namulonge. Seed samples from a total of 10 selected accessions (Table 1) of the three species of $P$. ahipa, $P$. tuberosus and $P$. erosus were collected. The choice of accessions from each species was based on results from on station germplasm evaluation at NaCRRI.

The collected yam bean seeds were cleaned to remove extraneous matter and then milled to fine flour using Hammer mill (8’ Laboratory Mill, Christy Hunt Agricultural Ltd, Suffolk-England) fitted with $0.5 \mathrm{~mm}$ screen. The flour was then stored in a refrigerator at $4^{\circ} \mathrm{C}$ until use. The seed flour sample destined for the determination of functional properties was defatted by mixing with hexane at a flour/solvent ratio of 1:10 w/v, for 24 hour with

Table 1. Samples of yam bean seeds that were collected from CIP.

\begin{tabular}{|c|c|c|c|c|}
\hline \multirow{2}{*}{$\begin{array}{l}\text { Species } \\
\text { P. ahipa }\end{array}$} & \multicolumn{4}{|c|}{ Selected accessions ${ }^{*}$} \\
\hline & 209031(UYB19) & 209033 (UYB21) & 209035 (UYB23) & 209006 (UYB03) \\
\hline P. tuberosus & 209060 (UYB40) & 209061 (UYB41) & 209054 (UYB35) & 209058 (UYB38) \\
\hline P. erosus ${ }^{* *}$ & 209017 (UYB06) & 209018 (UYB07) & & \\
\hline
\end{tabular}

${ }^{*}$ Accession codes in brackets are CIP-Uganda codes corresponding to CIP-Limacodes. ${ }^{* *}$ Two accessions (UYB 06 and UYB 07) from the $P$. erosus species were further selected for assessment of pasting and functional properties. 
constantstirring. The solvent was separated by centrifuging with a Fisher Scientific Centrific (225; Fisher Scientific, Pittsburg, PA, USA) at 6500 rpm for 15 minutes followed by air drying of the flour at room temperature for 8 hours. The defatted flour was stored at $4^{\circ} \mathrm{C}$ until use.

\subsection{Determination of Proximate Composition of Yam Bean Seeds and Defatted Yam Bean Seed Flours}

The proximate composition of the yam bean seed flours was determined by standard methods [6]. Moisture content was determined using the electric oven method at $105^{\circ} \mathrm{C}$ for 12 hours; crude protein content was determined by the Kjeldahl method using Foss Kjeltech ${ }^{\mathrm{TM}}$ auto distillation unit (8200, Type:10014901-Hilleroed, Denmark); crude fat was determined using the Soxhlet extraction method and total ash by dry ashing in an electric furnace at $550^{\circ} \mathrm{C}$ for 8 hours. Crude fiber was determined by the gravimetric method described by Pomeranz and Meloan [7]. The total carbohydrate was determined by difference [4].

\subsection{Functional Properties of Defatted Yam Bean Seed Flour}

\subsubsection{Bulk Density}

The bulk density of the defatted flour was determined according the method described by Butt and Batool [8]. Ten grams of sample were put into $100 \mathrm{ml}$ graduated cylinder and the cylinder was tapped several times (minimum 10 times) on the laboratory bench for the sample to settle, compact and eliminate air pockets. The volume was noted and the bulk density expressed as $\mathrm{g} / \mathrm{cm}^{3}$.

\subsubsection{Least Gelation Concentration}

This was determined according to the method described by Mugendi et al., [9]. Sample dispersions of 4, 6, 8, 10, 12 , and $14 \%(\mathrm{w} / \mathrm{v})$ were prepared in distilled water, adjusted to $\mathrm{pH} 7.0$ and mixed in a Waring Blender (Moulinex-Optiblend 2000 Trio, China) at the highest speed for 2 minutes. Five milliliters each, of the dispersions were poured into three test tubes and heated to $100^{\circ} \mathrm{C}$ in a water bath for 1 hour and cooled to $4^{\circ} \mathrm{C}$ in an ice bath. The lowest concentration at which all dispersions in triplicate formed gels that did not collapse or slip from inverted tubes was reported as the Least Gelation Concentration (LGC).

\subsubsection{Water and Oil Absorption Capacities}

Water and oil absorption capacities were determined according the method described by Appiah et al. [10]. One gram of each sample was mixed with $10 \mathrm{ml}$ distilled water (for water absorption capacity determination) or refined corn oil (for oil absorption capacity determination) in a pre-weighed $20 \mathrm{ml}$ centrifuge tube. The water and oil slurries (for both water absorption and oil absorption capacities) were agitated manually for 2 minutes, allowed to stand at $28^{\circ} \mathrm{C}$ for 30 minutes and then centrifuged using a centrifuge (225; Fisher Scientific, Pittsburg, PA, USA) at $650 \mathrm{rpm}$ for 20 minutes. The clear supernatant was decanted and discarded. The adhering drops of water or oil in the centrifuge tube were removed with cotton wool and the tube and its contents was weighed, the weight of water or oil absorbed by $1 \mathrm{~g}$ of flour or protein was calculated and expressed as water or fat absorption capacity.

\subsubsection{Protein Solubility}

Protein solubility was determined according to the method of Butt and Batool [8]. The flour sample (0.25 g) was homogenized in $20 \mathrm{ml}$ of $0.1 \mathrm{M} \mathrm{NaCl}$ at $\mathrm{pH} 7$ for 1 hour followed by centrifugation (225; Fisher Scientific, Pittsburg, PA, USA) at 5200 rpm for 30 minutes. Nitrogen content was determined in the supernatant and solubility was expressed as the percentage of total nitrogen of the original sample in the soluble fraction.

\subsubsection{Emulsifying Properties}

Emulsifying properties (emulsifying capacity and stability) were determined according to the method described by Butt and Batool [8]. Flour (1.8 g) was added to $25 \mathrm{ml}$ of distilled water (pH 7) and dispersed at maximum speed in a blender (Moulinex-Optiblend 2000 Trio, China). Corn oil (12.5 ml) was added and blended at high speed for 1 minute; the emulsion formed was equally divided into two $12 \mathrm{ml}$ centrifuge tubes and centrifuged using a centrifuge (225; Fisher Scientific, Pittsburg, PA, USA) for 5 minutes at 5200 rpm. Emulsion capacity was calculated as follows: 


$$
\text { Emulsion capacity }(\%)=\frac{\text { height of emulsified layer } \times 100}{\text { height of total contents of tube }} \text {. }
$$

Emulsion stability was determined in a similar way to that of emulsion capacity except that the emulsion was initially heated in a water bath at $85^{\circ} \mathrm{C}$ for 30 minutes and subsequently cooled to $25^{\circ} \mathrm{C}$ prior to centrifugation.

$$
\text { Emulsionstability }=\frac{\text { height of emulsified layer after heating } \times 100}{\text { height of total contents of tube }} \text {. }
$$

\subsubsection{Foaming Capacity and Stability}

The foaming capacity and stability were determined according the method of Butt and Batool [8]. Defatted yam bean seed flour was dispersed in distilled water to form $3 \%(\mathrm{w} / \mathrm{v})$ dispersion. A portion ( $50 \mathrm{ml})$ of the mixture was immediately transferred into a graduated cylinder and the volume recorded. This was followed by whipping the mixture using a blender (Moulinex-Optiblend 2000 Trio, China) for 4 minutes and volume after whipping was recorded. Foaming capacity was expressed as percentage volume change induced by whipping. The change in volume of foam after 60 minutes of standing at room temperature was recorded as foam stability.

$$
\begin{gathered}
\text { Foam capacity } \%=\frac{\text { volume after whipping }- \text { volume before whipping } \times 100}{\text { volume before whipping }} \\
\text { Foam stability }=\frac{\text { volume after standing }- \text { volume before whipping } \times 100}{\text { volume after whipping }- \text { volume before whipping }} .
\end{gathered}
$$

\subsection{Pasting Properties of Defatted Yam Bean Seed (P، erosus) Flour}

The pasting properties of defatted yam bean seed flours were analyzed with a Series 4 Rapid Visco Analyzer (RVA) (Newport Scientific from Australia) with Thermocline for Windows software. The analysis was done using standard one profile. The flour suspensions (6.72 g in $25.28 \mathrm{ml} \mathrm{H}_{2} \mathrm{O}$ ) corrected to $14 \%$ moisture content were exposed to the following time/temperature sequence: $50^{\circ} \mathrm{C}$ for 1 minute, heating from $50^{\circ} \mathrm{C}$ to $95^{\circ} \mathrm{C}$ at $12.16^{\circ} \mathrm{C}$ /minute, maintained at $95^{\circ} \mathrm{C}$ for 2.5 minutes, and cooled from $95^{\circ} \mathrm{C}$ to $50^{\circ} \mathrm{C}$ at $11.84^{\circ} \mathrm{C} /$ minutes rate. The apparent viscosity was expressed in RVU.

\subsection{Statistical Analysis}

All experimental analyses in this study were done in triplicates. All the data analysis was done using SPSS version 16.0 Software. Analysis of variance (ANOVA) was performed to generate treatment means and Least Significant Difference (LSD) $(\mathrm{P}<0.05)$ values were used to separate the means.

\section{Results and Discussion}

\subsection{Proximate Composition of Yam Bean Seed Flour}

Proximate composition (Table 2) showed that there were significant differences in all analyzed components of the seeds $P$. erosus, $P$. tuberosus and $P$. ahipa except for crude fiber. The results for crude protein and total lipids content in this study are in agreement with those reported by Grüneberg et al. [3] for all the three species. Grüneberg et al. [3] reported $P$. erosus, $P$. tuberosus and $P$. ahipa to have a protein content of $29.9 \%, 32.2 \%$ and $26.6 \%$, and oil content of $24.0 \%, 21.8 \%$ and $22.0 \%$, respectively. The results especially for the P. erosus in this study were only slightly higher than the ones reported by Santos et al. [4] which may be attributed to the difference in the geographical location and agronomical practices.

The results in this study revealed that the levels of protein and oil of yam bean seed are high compared to that of other legumes like chick peas which was reported to have $24.2 \mathrm{~g} / 100 \mathrm{~g}$ and $5.6 \mathrm{~g} / 100 \mathrm{~g}$ for crude protein and total fat, respectively [11]. Sayar et al. [11] reported that pea had 23.93, $3.12 \mathrm{~g} / 100 \mathrm{~g}$ while faba bean had 27.30 and $20.20 \mathrm{~g} / 100 \mathrm{~g}$ crude protein and fat content, respectively. The results in this study were close to those reported for soybean reported to have $42 \%$ and $20 \%$ protein and fat content, respectively [12]. Fernández-quintela, 
Table 2. Mean proximate composition of yam bean seeds from the three cultivated species (g/100g on dry matter basis).

\begin{tabular}{|c|c|c|c|}
\hline \multicolumn{4}{|c|}{ Species (number of accessions from each) } \\
\hline Composition & P. $\operatorname{erosus}(\mathrm{n}=2)$ & P. ahipa $(\mathrm{n}=4)$ & P. tuberosus $(\mathrm{n}=4)$ \\
\hline Moisture content & $6.48^{\mathrm{c}}(1.27)^{*}$ & $4.81^{\mathrm{a}}(0.72)$ & $5.97^{\mathrm{b}}(0.71)$ \\
\hline Crude protein & $30.13^{\mathrm{b}}(0.69)$ & $29.23^{\mathrm{a}}(2.07)$ & $32.16^{\mathrm{c}}(0.22)$ \\
\hline Total fat & $25.58^{\mathrm{c}}(0.82)$ & $25.04^{\mathrm{b}}(0.82)$ & $24.14^{\mathrm{a}}(2.28)$ \\
\hline Crude fiber & $8.07^{\mathrm{b}}(0.47)$ & $7.48^{\mathrm{b}}(0.65)$ & $4.18^{\mathrm{a}}(0.26)$ \\
\hline Total ash & $3.36^{\mathrm{a}}(0.04)$ & $3.91^{\mathrm{b}}(0.14)$ & $4.12^{\mathrm{C}}(0.25)$ \\
\hline Total carbohydrates & $32.10^{\mathrm{b}}(0.39)$ & $34.54^{\mathrm{c}}(2.70)$ & $28.67^{\mathrm{a}}(5.53)$ \\
\hline
\end{tabular}

Means values in the same row with different superscript letters are significantly different $(\mathrm{P} \leq 0.05)$. ${ }^{*}$ Values in parentheses are standard error (SE) of the respective means.

Macarulla, Del Barrio and Martînez [13] reported soya bean protein and fat content of 36.69 and 22.43 g/100g, respectively. The total carbohydrate content of the yam bean seed, though higher than that reported for soybean (18.83 g/100g) [13] was lower than that of other legumes like pea (59.39) [13] and faba beans (52.12 g/100g) [13].

The oil content in the yam bean seeds is only lower than that of Arachis hypogaea (peanut) among legumes [4]. The high oil content of yam bean seed makes it a potential source of oil. Grüneberg et al. [3] noted the vegetable fat with high concentrations of saturated fatty acids such as yam bean seeds is desired by the food industry, especially to avoid the need for hydrogenation and transesterification processes in the production of margarine and related products. Due to toxin rotenone that is highly soluble in oil [3] [4], the yam bean seed oil has more potential for use in non-food applications like bio-diesel and agricultural chemicals.

\subsection{Proximate Composition of Defatted Yam Bean (P، erosus) Flour}

The results of proximate composition of defatted yam seed flour (Table 3) showed that there was no significant difference in the moisture content, total ash, crude fibre and residual total fat of the two accessions of $P$. erosus that were analyzed in this study. However the crude protein and total carbohydrates of the two accessions were significantly different $(\mathrm{P} \leq 0.05)$. The defatted flour from the two accessions of $P$. erosus exhibited higher protein and carbohydrate content than that of the seed (Table 2).

Defatting with hexane resulted in an apparent increase in the protein and other nutrient contents, which is attributable to the removal of the lipids and lipid soluble components. With regard to the high protein content, the yam bean seed flour has potential to be used in a variety of food and non food industrial applications. The direct use of defatted flours as functional ingredients play an important role in industries because of their lower production cost compared to that of protein concentrates [14]. However, the use of these flours depends on their performance as functional ingredients and their behavior in particular food systems [14].

\subsection{Functional Properties of the Defatted Yam Bean Seed Flour from Two Accessions of $P$, erosus}

The measured functional properties did not show significant difference between the two accessions of $P$. erosus studied (Table 4). This was expected as the two accessions are from the same species and probably are closely related.

\subsubsection{Bulk Density}

Bulk density depicts the behaviour of the material in dry mixes and is an important parameter that can determine packaging requirements of the product [15]. The bulk density result for the yam bean seed flour from this study were slightly higher compared to $0.55-0.62 \mathrm{~g} / \mathrm{cm}^{3}$ reported for tigernut (Cyoperus esculentus) seed flour [17], $0.53 \mathrm{~g} / \mathrm{cm}^{3}$ for defatted chick pea [18] and lower than $0.63 \mathrm{~g} / \mathrm{cm}^{3}$ for soybean protein meal [16]. Amadou, Tidjani, 
Table 3. Mean proximate composition of defatted yam bean (P. erosus) flour for the two accessions on dry matter basis.

\begin{tabular}{ccc}
\hline Component & Defatted yam bean seed flour \\
\hline & UYB06 (g/100g) & UYB07 (g/100g) \\
Moisture & $10.45^{\mathrm{a}} \pm 0.11$ & $10.47^{\mathrm{a}} \pm 0.16$ \\
Crude protein & $45.57^{\mathrm{a}} \pm 1.20$ & $48.78^{\mathrm{b}} \pm 2.63$ \\
Total fat & $5.16^{\mathrm{a}} \pm 0.03$ & $5.16^{\mathrm{a}} \pm 0.06$ \\
Crude fiber & $6.74^{\mathrm{a}} \pm 0.03$ & $7.13^{\mathrm{a}} \pm 0.10$ \\
Ash & $6.0^{\mathrm{a}} \pm 0.03$ & $6.38^{\mathrm{a}} \pm 0.09$ \\
Total Carbohydrates & $36.50^{\mathrm{b}} \pm 1.11$ & $32.55^{\mathrm{a}} \pm 2.41$ \\
\hline
\end{tabular}

The values in the table are means of triplicate determinations $\pm \mathrm{SD}$. Mean values in the same row with different superscript letters are significantly different $(\mathrm{P} \leq 0.005)$.

Table 4. Functional properties of defatted yam bean seed flour for the two accessions of P. erosus.

\begin{tabular}{ccc}
\hline & & \\
Functional properties & Accession \\
\cline { 2 - 3 } & 209017 (UYB 06) & 209018 (UYB 07) \\
\hline Bulk density $\left(\mathrm{g} / \mathrm{cm}^{3}\right)$ & $0.59^{\mathrm{a}} \pm 0.00$ & $0.59^{\mathrm{a}} \pm 0.00$ \\
Least gelation concentration (\%) & $14.00^{\mathrm{a}} \pm 0.00$ & $14.00^{\mathrm{a}} \pm 0.00$ \\
Water absorption capacity (g/g) & $2.81^{\mathrm{a}} \pm 0.02$ & $2.90^{\mathrm{a}} \pm 0.04$ \\
Oil absorption capacity (g/g) & $1.52^{\mathrm{a}} \pm 0.02$ & $1.48^{\mathrm{a}} \pm 0.02$ \\
Emulsion capacity (\%) & $35.70^{\mathrm{a}} \pm 1.40$ & $36.02^{\mathrm{a}} \pm 2.80$ \\
Emulsion stability (\%) & $33.45^{\mathrm{a}} \pm 6.10$ & $32.15^{\mathrm{a}} \pm 8.37$ \\
Foaming capacity (\%) & $42.00^{\mathrm{a}} \pm 2.00$ & $42.00^{\mathrm{a}} \pm 3.46$ \\
Foam stability (\%) & $25.80^{\mathrm{a}} \pm 6.19$ & $25.10^{\mathrm{a}} \pm 5.22$ \\
Protein solubility (\%) & $70.35^{\mathrm{a}} \pm 1.25$ & $68.00^{\mathrm{a}} \pm 1.90$ \\
\hline
\end{tabular}

The values indicated in the table are means of triplicate determinations \pm SD. Mean values in the same row with the same superscripts are not significantly different $(\mathrm{P} \leq 0.05)$ for various functional properties of two accessions of yam bean seed flours.

Foh, Kamara and Guo-Wei [16] reported that the bulk density of the flour would vary with the particle size or fineness of the flour.

\subsubsection{Least Gelation Concentration (LGC)}

Gelation is an aggregation of denatured protein molecules. The LGC results for yam bean seed flours in this study were similar to the results reported for lupin seed flour (14\%) [19]. Gelation properties are related to water absorption capacities hence the high water absorption capacity recorded for the yam bean flours in this study could explain the good gel formation capacity. Adebowale, Sanni and Awonorin [20] noted that gelation takes place more readily at higher protein concentration because of greater intermolecular contact during heating and that high protein solubility is always necessary for gelation. The high LGC observed in the yam bean seed defatted flour may be a disadvantage in respect to the production of some products such as curd since production of such, calls for materials with high gelation capacity like milk protein (casein) [20]. Use of defatted yam bean seed flour for gelation applications may therefore, require modification prior to use.

\subsubsection{Water and Oil Absorption Capacity}

Water and oil absorption capacities (WAC, OAC) are useful indices of the ability of the protein in the material to prevent fluid loss from a product during food storage or processing [21]. The intrinsic factors that affect water binding properties of food flours with relatively high protein content relate to amino acid composition, protein conformation and surface polarity [22]. 
The results of WAC for the defatted yam bean seed flours exhibited no significant difference between the two accessions (UYB 06 and UYB 07) (Table 4). These results are close to those reported by Fekria et al. [22] for the defatted ground nut which ranged from 3.03 to $3.07 \mathrm{ml} / \mathrm{g}$ for two groundnut varieties. The WAC for yam been seed flour in this study was higher than that reported by Hussain et al. [23] for defatted flax seed protein concentrate $(2.2 \mathrm{~g} / \mathrm{g})$. However WAC for yam been seed in this study was lower than $4.94 \mathrm{~g} / \mathrm{g}$ reported that for defatted chickpea flour [18]. The variation in WAC of defatted yambean seed flour and other legumes may be attributed to the difference in protein structure and the presence of different hydrophilic carbohydrates. Flours with high WAC tend to have more hydrophilic polysaccharide and protein constituents [22]. The high water absorption capacity of the defatted yam bean seed flour makes it desirable for use in meats, sausage, bread, mayonnaise and cakes.

The defatted yam bean seed flour showed moderate oil absorption capacity (OAC) (Table 4) compared to other legume seeds. The observed OAC values were lower than $2.60 \mathrm{~g} / \mathrm{g}$ for chick pea flour [18] and 2.87 and $2.93 \mathrm{ml} / \mathrm{g}$ for defatted ground nut flour [22]. However the OAC values for flours in this study were higher than those reported for defatted flax seed flour $(1.04 \mathrm{~g} / \mathrm{g})$ [23]. The low OAC means the flour could be used as a coating in deep fat frying to reduce oil absorption by the fried food.

Interactions of water and oil with proteins are very important in food systems because of their effects on the flavor and texture of foods [16]. Fekria et al. [22] reported that the ability of the flour to absorb and retain water and oil may help to improve the binding capacity and enhance flavor retention, improve mouthfeel and reduce moisture and fat losses of extended meat products. Valim and Batistuti [18] observed that extrusion cooking helps to enhance the oil absorption capacity of defatted legume flour probably due to the dissociation of the proteins which exposes non polar amino acid residues to interact with oil molecule.

\subsubsection{Emulsifying Capacity and Stability}

The formation and stability of emulsions is very important in food systems such in mayonnaise and the emulsifying properties are usually attributed to the flexibility of solutes and exposure of hydrophobic domains [22]. The flours from the two yam bean accessions (UYB 06 and UYB 07) studied exhibited moderate emulsifying capacity (EC) values as well as emulsion stability (ES) (Table 4) as compared to the conventional legumes. The EC and ES values recorded for yam bean seed flour were higher than $22.9 \%-28.3 \%$ and $11.3 \%-13.8 \%$, respectively reported for defatted groundnut flour [22]. However the results in this study for EC and ES were lower than $51 \%$ and $50 \%$ reported for defatted Baru nut flour, respectively [14]. Yam bean seed flour had almost half (EC of 74\% and ES value of $72 \%$ ) the emulsification properties of egg york powder one of the excellent emulsifiers [24].

Several natural and processed foods, such as milk, egg yolk, coconut milk, soy milk, butter, margarine, mayonnaise, spreads, salad dressings, frozen desserts, frankfurter, sausage, and cakes, are emulsion-type products where proteins play an important role as emulsifiers [25]. Plant proteins normally have poor surface activity compared to animal protein such as ovalbumin and bovine serum albumin which are widely utilized for emulsification role in food systems [25]. The difference in the surface activity between the plant and animal protein is related to the difference in protein conformation [25] and the presence of other macronutrients such as carbohydrates which may not necessarily have good emulsification properties. Highly flexible molecules, such as caseins, can undergo rapid conformational changes once they are adsorbed at the interface, enabling additional polypeptide segments to bind to the interface while on the contrary, the rigid globular proteins, such as legume seed proteins, cannot undergo extensive conformational changes at the interface [25].

Proteins with high emulsifying capacity such as egg york is good for products such as salad dressing, sausages, bologna, soups, confectionery, frozen dessert and cakes [26]. The results from this study show that the defatted yam bean seed flour due to its moderate emulsion capacity and stability may not be suitable for use in food system where formation and stabilization of emulsion is important such as in mayonnaise, cakes and frozen desserts among others unless modifications are made to the material to improve on its surface active properties.

\subsubsection{Foaming Capacity and Stability}

The foaming capacity (FC) of a protein refers to the amount of interfacial area that can be created by the protein while foam stability refers to the ability of protein to stabilize against gravitational and mechanical stresses. Foam formation and stability are a function of the type of protein, $\mathrm{pH}$, processing methods, viscosity and surface tension [22].The values for foaming capacity recorded in this study (Table 4) were higher than those reported for defatted ground nut flour (4\% - 4.2\%) [22], but lower than those reported for defatted Baru nut flour (69\%) 
at $\mathrm{pH} 7$ [14]. On the other hand the values for Foam stability of yam bean seed flour were lower than those reported for defatted ground nut flour (97\% - 97.50\%) [22] and those of defatted Baru nut flour (35\%) [14].

Egg white powder which is widely used for its excellent foaming characteristics has been reported to have higher FC values of $97.5 \%$ and FS values of $78.3 \%$ [24]. Result from this study indicate that the defatted yam bean seed flour has potential for application in food systems that require high percentage of porosity such as ice cream and cakes as well as in non food products as a foaming agent.

\subsubsection{Protein Solubility}

Protein solubility is probably the most critical functional property since it affects other properties such as emulsification, foaming and gelation (Fekria et al., 2012). Protein solubility is influenced by many factors such as origin of the protein, processing conditions, $\mathrm{pH}$, ionic strength as well as presence of other ingredients [22].The Protein solubility values recorded for the yam bean seed flour in this study (Table 4) were higher than $53.3 \%$ for defatted chick pea flour [18] and 10\% - 15\% for defatted groundnut flour [22]. Khalid et al. [19] reported protein solubility of $80 \%$ for defatted cowpea flour at $\mathrm{pH} 7$.

Industrial application of proteins such as in the production of fibres, adhesives, ingredients of coating, emulsifiers, food additives and different food products depend upon bringing proteineous materials into solution [27]. Therefore knowledge of protein solubility is vital in selection of particular vegetable proteins for possible industrial applications. The high protein solubility exhibited by $P$. erosus is an indicator that the flour may have potential for industrial applications.

\subsection{Pasting Properties of Defatted Yam Bean (P. erosus) Seed Flour}

When flours are heated in an aqueous environment, they undergo a series of changes known constituting gelatinization and pasting [28]. These are two of the most important properties that influence quality and aesthetic considerations in the food and allied industries, since they affect texture and digestibility as well as the end use of starchy foods [28].

The pasting temperature provides an indication of the minimum temperature required for cooking [29]. Pasting temperature has been reported to relate to water binding capacity (WAC). A higher pasting temperature implies higher water binding capacity, higher gelatinization, and lower swelling property of starch due to a high degree of association between starch granules [28]. The pasting temperatures of the two accessions of $P$. erosus (UYB 06 and UYB 07) were significantly different $(\mathrm{P} \leq 0.05)$ (Table 5 and Figure 1). Other studies have reported values of pasting temperatures for legumes ranging from $73^{\circ} \mathrm{C}$ for defatted African walnut flour [30], $81.63^{\circ} \mathrm{C}$ for black bean flour [31] to values of $88.25^{\circ} \mathrm{C}$ [29] for Brachystegia eurycoma seed flour. The pasting temperature of the defatted yam bean seed flour was therefore within the range reported for other legumes.

Peak viscosity reflects the ability of starch to swell freely before their physical breakdown [28]. Peak viscosityfor yam bean seed flour (Table 5) were lower than those of other legume seed flours like the defatted African walnut flour having 183.0 RVU [30] and undehulled black bean flour having $247 \mathrm{RVU}$ [31] but higher than the values of 77.58 RVU reported for Brachystegia Eurycoma seed flour [29].

The peak viscosity indicates the water binding capacity of the flour [29] and is often correlated with final product quality as well as providing an indication of the viscous load likely to be encountered by a mixing cooker [28]. The relatively high peak viscosity exhibited by $P$. erosus flours compared to other legume flours is indicative that $P$. erosus flour may be suitable for products requiring high gel strength and elasticity [28].

The trough viscosity, which is the minimum value in constant temperature phase of the RVA profile, measures the ability of the paste to withstand breakdown during hot and constant shear conditions. The defatted yam bean seed flour for the two accessions (UYB 06 and UYB 07) of $P$. erosus exhibited lower trough viscosities compared to those reported for corn flour (225.5 RVU) and Brachystegia eurycoma seed flour (229.25 RVU) [29]. The break down viscosity of the defatted yam bean seed flour was almost similar to those reported for Brachystegia eurycoma seed flour (53.8 RVU) and its starch (46.17 RVU) and slightly higher than values for corn starch (41.58 RVU) [29]. Low stability of starch paste is associated with high value of breakdown [28]. The lower the break downviscosity the higher the ability of the flour to withstand heating and shear stress during processing [29]. Therefore defatted yam bean seed flour should be able to withstand heating and shear processes without significant change in consistence.

The final viscosity which is the viscosity after holding cooked starch at $50^{\circ} \mathrm{C}$ and represents cooked starch 


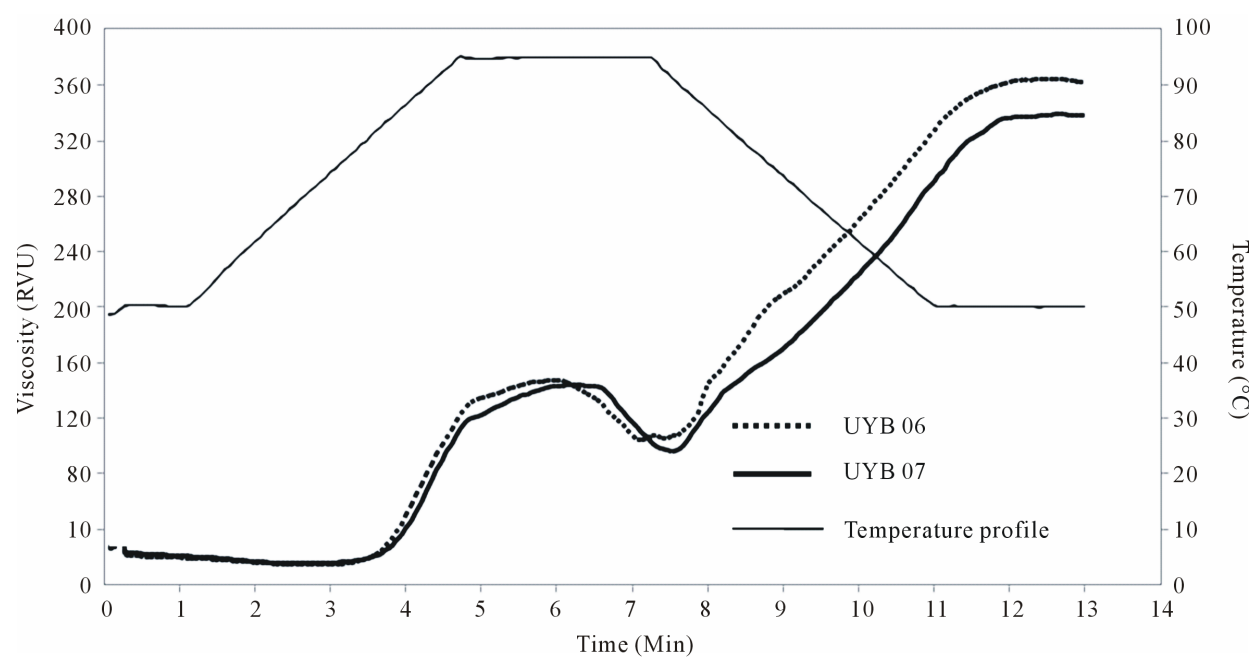

Figure 1. Pasting curves of defatted yam bean (P. erosus) seed flour from two accessions (UYB 06 and UYB 07) obtained from RVA analysis.

Table 5. Pasting characteristics of defatted yam bean (P. erosus) flour for two accessions**.

\begin{tabular}{|c|c|c|c|c|c|c|c|}
\hline \multirow[b]{2}{*}{ Sample } & \multirow[b]{2}{*}{$\begin{array}{c}\text { Peak } \\
\text { Time/Min }\end{array}$} & \multirow[b]{2}{*}{$\begin{array}{c}\text { Pasting } \\
\text { Temp } /{ }^{\circ} \mathrm{C}\end{array}$} & \multicolumn{5}{|c|}{ Viscosity/RVU } \\
\hline & & & $\begin{array}{c}\text { Peak } \\
\text { Viscosity }\end{array}$ & $\begin{array}{c}\text { Trough } \\
\text { Viscosity }\end{array}$ & Break Down & $\begin{array}{c}\text { Final } \\
\text { Viscosity }\end{array}$ & Setback \\
\hline UYB 06 & $6.15^{\mathrm{a}} \pm 0.20$ & $79.97^{\mathrm{a}} \pm 0.06$ & $145.50^{\mathrm{a}} \pm 2.11$ & $\begin{array}{c}102.03^{\mathrm{a}} \pm \\
2.14\end{array}$ & $43.47^{\mathrm{a}} \pm 0.05$ & $360.14^{\mathrm{a}} \pm 5.55$ & $\begin{array}{c}258.11^{\mathrm{a}} \pm \\
3.80\end{array}$ \\
\hline UYB 07 & $6.11^{\mathrm{a}} \pm 0.08$ & $81.33^{\mathrm{b}} \pm 0.46$ & $146.72^{a} \pm 3.10$ & $95.11^{\mathrm{b}} \pm 0.83$ & $51.61^{\mathrm{b}} \pm 3.92$ & $347.97^{\mathrm{a}} \pm 10.46$ & $\begin{array}{c}252.86^{\mathrm{a}} \pm \\
11.28\end{array}$ \\
\hline
\end{tabular}

*Values in the table are means of triplicate determinations \pm SD. Means in the same column with same superscript letter are significantly different $(\mathrm{P} \leq$ $0.05)$.

stability. The final viscosity was almost twice the peak viscosity (Table 5 and Figure 1). Final viscosity is used to define the quality of the particular starch and indicate the stability of the cooked paste in actual use. It also shows the ability of the material to form a paste or gel after cooling as well the resistance of the paste to shear force during stirring [28].The set back values of the yam bean seed flour in this study (Table 5) were higher than those reported for corn starch (215.67 RVU) [29]. The higher setback values indicate higher potential for retrogradation during cooling of the products that is made from the flour [32]. Setback involves retrogradation or re-ordering of the starch molecules and setback viscosity has been correlated with the texture of various products [28]. High setback value is also associated with syneresis, or weeping especially during freeze/thaw cycles [28].

\section{Conclusion}

The study established that yam bean seed flour has good characteristics which can foster its use in both food and non food systems. The results of pasting and functional characteristics observed in the study indicated that defatted yam bean seed flour has potential industrial applications and these may include: manufacture of fillers, emulsifiers, stabiliser, paper, adhesives, bioplastics among others. Yam bean seed flour, however exhibited rather low emulsion and foaming capacities compared to other legume seed flours and therefore may not be suitable for use in products or systems that require emulsification or foaming. If rotenone can be economically and effectively removed from yam bean seed, the flour could gain application in food processing as a functional ingredient otherwise the starch and protein yam bean seed flour could be considered for non food industrial applications such as in the paper, adhesive, bioplastics and textile industries. 


\section{Acknowledgements}

The authors acknowledge the International Potato Centre for the financial and technical support that made this work possible under her Belgium Technical Cooperation funded project "Enhancing the nutrient rich yam bean (Pachyrhizus spp.) to improve food quality and availability and sustainability of farming systems in Central and West Africa."

\section{References}

[1] Bhat, R. and Karim, R.R. (2009) Exploring the Nutritional Potential of Wild and Underutilized Legumes. Comprehensive Reviews in Food Science and Food Safety, 8, 305-333. http://dx.doi.org/10.1111/j.1541-4337.2009.00084.x

[2] Zanklan, A.S., Ahouangonou, S., Heiko, C.B., Pawelzik, E. and Grüneberg, W.J. (2007) Evaluation of the Storage Root-Forming Legume Yam Bean (Pachyrhizus ssp.) under West African Conditions. Crop Science, 47, 1934-1946. http://dx.doi.org/10.2135/cropsci2006.03.0153

[3] Grüneberg, W.J., Goffman, F.D. and Velasco, L. (1999) Characterization of Yam Bean (Pachyrhizus spp.) Seeds as Potential Sources of High Palmitic Acid Oil. Journal of the America Oil Chemists' Society, 76, 1309-1312.

[4] Santos, A.C., Cavalcanti, M.S. and Coelho, L.C. (1996) Chemical Composition and Nutritional Potential of Yam Bean Seeds (Pachyrhizus erosus L. urban). Plant Foods for Human Nutrition, 49, 35-41. http://dx.doi.org/10.1007/BF01092520

[5] Sai-Ut, S., Ketnawa, S., Chaiwut, P. and Rawdkuen, S. (2009) Biochemical and Functional Properties of Proteins from Red Kidney, Navy and Adzuki Beans. Asian Journal of Food and Agro-Industry, 2, 493-504.

[6] AOAC (2000) Official Methods of Analysis International. $17^{\text {th }}$ Edition, Association of Official Analytical Chemists, Washington DC.

[7] Pomeranz, Y. and Meloan, E.C. (1994) Food Analysis: Theory and Practice. $3^{\text {rd }}$ Edition, Chapman and Hall, New York.

[8] Butt, S.M. and Batool, R. (2010) Nutritional and Functional Properties of Some Promising Legumes Protein Isolates. Pakistan Journal of Nutrition, 9, 373-379. http://dx.doi.org/10.3923/pjn.2010.373.379

[9] Mugendi, J.B.W., Njagi, E.N.M., Kuria, E.N., Mwasaru, M.A., Mureithi, J.G. and Apostolides, Z. (2010) Nutritional Quality and Physicochemical Properties of Mucuna Bean (Mucuna pruriens L.) Protein Isolates. International Food Research Journal, 17, 357-366.

[10] Appiah, F., Asibuo, Y.J. and Kumah, P. (2011) Physicochemical and Functional Properties of Bean Flours of Three Cowpea (Vigna unguiculata L. Walp) Varieties in Ghana. African Journal of Food Science, 5, 100-104.

[11] Sayar, S., Koksel, H. and Turhan, M. (2005) The Effects of Protein Rich Fraction and Defatting on Pasting Behavior of Chickpea Starch. Starch-Stärke, 57, 599-604. http://dx.doi.org/10.1002/star.200500397

[12] Berk, Z. (1992) Technology of Production of Edible Flour and Protein Products from Soybeans. Technion, Israel Institute of Technology, Haifa, FAO Agricultural Services Bulletin No. 97.

[13] Fernández-Quintela, A., Macarulla, M.T., Del Barrio, A.S. and Martinez, J.A. (1997) Composition and Functional Properties of Protein Isolates Obtained from Commercial Legumes Grown in Northern Spain. Plant Foods for Human Nutrition, 51, 331-341. http://dx.doi.org/10.1023/A:1007936930354

[14] Guimarães, R.C.A., Favaro, S.P., Viana, A.C.A., Neto, J.A.B., Neves, V.A. and Honer, M.R. (2012) Study of the Proteins in the Defatted Flour and Protein Concentrate of Baru Nuts (Dipteryx alata Vog). Ciência e Tecnologia de Alimentos. Campinas, 32, 464-470.

[15] Mohamed, T.K., Zhu, K., Issoufou, A., Fatmata, T. and Zhou, H. (2009) Functionality, in Vitro Digestibility and Physicochemical Properties of Two Varieties of Defatted Foxtail Millet Protein Concentrates. International Journal of Molecular Sciences, 10, 5224-5238. http://dx.doi.org/10.3390/ijms10125224

[16] Amadou, I., Amza, T., Foh, M.B.K., Kamara, M.T. and Le, G.W. (2010) Influence of Lactobacillus plantarum Lp6 Fermentation on the Functional Properties of Soybean Protein Meal. Emirates Journal of Food and Agriculture, 22, 456-465. http://dx.doi.org/10.9755/ejfa.v22i6.4663

[17] Oladele, A.K. and Aina, J.O. (2007) Chemical Composition and Functional Properties of Flour Produced from Two Varieties of Tigernut (Cyperus esculentus). African Journal of Biotechnology, 6, 2473-2476.

[18] Valim, M.F.C.F.A. and Batistuti, J.P. (1998) Functional Properties of Defatted Chick Pea (Cicer arietinum, L.) Flour as Influenced by Thermoplastic Extrusion. Alimentos e Nutrição Araraquara, 9, 65-75.

[19] Khalid, I.I., Elhardallou, S.B. and Elkhalifa, E.A. (2012) Composition and Functional Properties of Cowpea (Vigna unguiculata L. Walp) Flour and Protein Isolates. American Journal of Food Technology, 7, 113-122. http://dx.doi.org/10.3923/ajft.2012.113.122 
[20] Adebowale, A.A., Sanni, L.O. and Awonorin, S.O. (2005) Effect of Texture Modifiers on the Physicochemical and Sensory Properties of Dried Fufu. Food Science and Technology International, 11, 373-382. http://dx.doi.org/10.1177/1082013205058531

[21] Kiosseoglou, V. and Paraskevopoulou, A. (2011) Functional and Physicochemical Properties of Pulse Proteins. In: Tiwari, K.B., Gowen, A. and McKenna, B., Eds., Pulse Food: Processing, Quality and Nutraceutical Applications, Elsevier Inc., London, 57-90.

[22] Fekria, A.M., Isam, A.M.A., Suha, O.A. and Elfadil, E.B. (2012) Nutritional and Functional Characterization of Defatted Seed Cake Flour of Two Sudanese Groundnut (Arachis hypogaea) Cultivars. International Food Research Journal, 19, 629-637.

[23] Hussain, S., Anjum, F.M., Butt, M.S. and Sheikh, M.A. (2008) Chemical Compositions and Functional Properties of Flaxseed Flour. Sarhad Journal of Agriculture, 24, 649-653.

[24] Ndife, J., Udobi, Ejikeme, C. and Amaechi, N. (2010) Effect of Oven Drying on the Functional and Nutritional Properties of Whole Egg and Its Components. African Journal of Food Science, 4, 254-257.

[25] Damodaran, S. (1996) Amino Acids, Peptides and Proteins. In: Fennema, R.O., Food Chemistry, 3rd Edition, CRC Press, New York, 321-416.

[26] Nassar, A.G. (2008) Chemical Composition and Functional Properties of Prickly Pear (Opuntia ficus indica) Seeds Flour and Protein Concentrate. World Journal of Dairy \& Food Sciences, 3, 11-16.

[27] Adebowale, A.Y. (2008) A Study of the Control Variables during the Preparation of Protein Isolate from Mucuna Bean (Mucuna pruriens). Electronic Journal of Environmental, Agricultural and Food Chemistry, 7, 3223-3238. http://www.scimagojr.com/journalsearch.php?q=6400153124\&tip=sid\&clean=0

[28] Maziya-Dixon, B., Adebowale, A.A., Onabanjo, O.O. and Dixon, A.G.O. (2005) Effect of Variety and Drying Methods on Physico-Chemical Properties of High Quality Cassava Flour from Yellow Cassava Roots. African Crop Science Conference Proceedings, 7, 635-641.

[29] Ikegwu, O.J., Okechukwu, P.E. and Ekumankana, E.O. (2010) Physico-Chemical and Pasting Characteristics of Flour and Starch from Achi Brachystegia Eurycoma Seed. Journal of Food Technology, 8, 58-66. http://dx.doi.org/10.3923/jftech.2010.58.66

[30] Ndie, E.C., Nnamani, C.V. and Oselebe, H.O. (2010) Some Physicochemical Characteristics of Defatted Flours Derived from African Walnut (Tetracarpidium conoforum): An Underutilized Legume. Pakistan Journal of Nutrition, 9, 909-911. http://dx.doi.org/10.3923/pjn.2010.909.911

[31] Akinjayeju, O. and Ajayi, F.O. (2011) Effects of Dehulling on Functional and Sensory Properties of Flours from Black Beans (Phaseolus Vulgaris). Food and Nutrition Sciences, 2, 344-349. http://dx.doi.org/10.4236/fns.2011.24049

[32] Oluwalana, I.B., Oluwamukomi, M.O., Fagbemi, T.N. and Oluwafemi, G.I. (2011) Effects of Temperature and Period of Blanching on the Pasting and Functional Properties of Plantain (Musa parasidiaca) Flour. Journal of Stored Products and Postharvest Research, 2, 164-169. 